\title{
Études/Inuit/Studies
}

\section{DAVELUY, Michelle, Francis LÉVESQUE and Jenanne FERGUSON (eds), 2011 Humanizing Security in the Arctic, Edmonton, Canadian Circumpolar Institute Press, Occasional Publications Series, 68, 316 pages.}

\section{P. Whitney Lackenbauer}

Volume 37, numéro 2, 2013

URI : https://id.erudit.org/iderudit/1025717ar

DOI : https://doi.org/10.7202/1025717ar

Aller au sommaire du numéro

Éditeur(s)

Association Inuksiutiit Katimajiit Inc.

Centre interuniversitaire d'études et de recherches autochtones (CIÉRA)

ISSN

0701-1008 (imprimé)

1708-5268 (numérique)

Découvrir la revue

Citer ce compte rendu

Lackenbauer, P. (2013). Compte rendu de [DAVELUY, Michelle, Francis LÉVESQUE and Jenanne FERGUSON (eds), 2011 Humanizing Security in the Arctic, Edmonton, Canadian Circumpolar Institute Press, Occasional Publications Series, 68, 316 pages.] Etudes/Inuit/Studies, 37(2), 201-203. https://doi.org/10.7202/1025717ar d'utilisation que vous pouvez consulter en ligne. 


\section{Recensions / Book Reviews}

DAVELUY, Michelle, Francis LÉVESQUE and Jenanne FERGUSON (eds)

2011 Humanizing Security in the Arctic, Edmonton, Canadian Circumpolar Institute Press, Occasional Publications Series, 68, 316 pages.

The papers in Humanizing Security in the Arctic are derived from the 2009 Summer Seminar of the International PhD School for Studies of Arctic Societies (IPSSAS), featuring nine North American and European universities. A broad range of contributors - academics, consultants, even a politician from Nunavut-cover a wide range of historical and contemporary topics: sustainability and relationships between Aboriginal peoples; local sovereignty and stewardship; food and linguistic (in)securities; accessibility of education; and transnational sociocultural movementsto name but a few. The plurality of voices and perspectives is both the strength and the weakness of the book. It reinforces the message that security extends far beyond narrow military/state security articulations and can be "humanized" and interrogated in all forms of socio-political interaction. It also reveals how a broad definition of "human security" or "cultural security" can render the concept tautological.

Unfortunately, the thin introduction makes no substantive attempt at theorising concepts of security or human security whatsoever. This unfortunate omission is not compensated by Milton Freeman and Edna Elias' opening contributions on contested knowledge systems and urban Inuit identities. As a result, the chapters in this eclectic volume are left to stand on their own and thus reflect the usual problem of workshop proceedings covering a disparate array of subjects. No unifying thread stitches them together or encourages engagement between the chapters, and the reader cannot help but feel that many of the authors simply inserted the word "security" once or twice at the editors' request. There is no conclusion and, disappointingly, no index, which would have helped researchers navigate the text for topics of particular interest.

Nevertheless, readers should find several individual chapters interesting and illuminating. For example, when Nunavut politician Ron Elliott sums up the issues discussed at the inaugural meeting of the High Arctic Council in early 2009, he reveals how local politicians and administrators attempted to "humanize" the federal emphasis on sovereignty by expanding it to include transportation, food security, and high costs of living. It is fascinating to read Ole Marquardt's analysis of the discourse surrounding people of mixed Greenlandic-Danish ancestry and seal hunting competency, and Inge Host Seiding's exploration of colonial governance and intermarriage-even though connections to "security" are tenuous. Christopher Fletcher creatively interrogates the evolving role of inuksuit as symbols of Canadian identity and sovereignty. Unfortunately, he fails to develop the connection to security, even in the context of Hans Island. Other chapters shed light on local Alaskan concerns about changing 
subsistence practices and concomitant effects on culture and food (in)security. Especially superb is Zoe Todd's analysis of food security in Paulatuk, although its theoretical backdrop could more carefully interrogate intersections between sovereignty and security discourses rather than treating the two concepts as synonymous.

Other chapters are less well-developed. Some are aspiring outlines of dissertation projects in progress or think pieces backed by limited evidence or engagement with existing scholarship. Others, such as those by Naullaq Arnaquq, Alexina Kublu, and Carole Cancel on Inuit language, never bother to mention "security" whatsoever. It is peculiar to see the editors include Ian MacLaren's piece on Jasper National Park in a volume on the Arctic, and this chapter raises questions about whether they should have wielded a more discriminate editorial hand in deciding what to include in this particular collection.

Although Humanizing Security in the Arctic had an explicit objective "to critically assess the notion of security in the context of the Arctic," the editors' lack of overarching engagement with the rich theoretical literature on this subject left this volume little more than a sum of its (uneven) individual parts. Kennet Pedersen's final reflection on the links between interpretation and security may appeal to cultural anthropologists, but neither he nor other contributors sufficiently engage other disciplinary approaches. Although individual authors make reference to various forms of (in)security, e.g., cultural, food, linguistic, educational, environmental, economic, no coherent framework emerges to explore what is attempted or gained by applying the "security" label to these challenges. For example, securitisation theory (never mentioned in the book) posits that a security issue is produced after a securitising actor presents it as an existential threat and convinces decision-makers that it must be addressed outside "normal" politics. Few of the authors critically reflect on their articulation of security threats and how these "speech acts" themselves are part of strategic and pragmatic processes.

Contributor Raila Salokangas asserts: "Sceptics might say that the phrase 'educational security' is just another buzz-word, like 'lifelong learning,' 'social economy,' or 'ecotourism.' Does wording matter when the problem stays the same? I believe that as long as people are conscious of the definitions and connections to certain definitions, buzz-words do not matter" (p. 279). My disappointment is not a casual dismissal of "security" as a buzz-word, but from its indiscriminate application to anything that poses problems or challenges to Arctic people(s). Accordingly, I came away feeling that the volume as titled sets up false expectations. Pedersen ends with the simple note that the seminar from which these papers emerged confirmed "that there is a lot to be learned from the study of the concrete lifeways of ordinary people in palpable places and existential serious spaces; persons who might be enmeshed in many facets of global culture even though they can't afford a flight ticket out" (p. 312). True enough. Diligent readers will find some interesting reflections herein, even if the collection as a whole provides less clarity on the concept of security than it does on a spate of human challenges facing the people of the Circumpolar North. 
P. Whitney Lackenbauer Department of History

St. Jerome's University 290 Westmount Road North

Waterloo, Ontario N2L 3G3, Canada

\section{PHARAND, Sylvie}

2012 Caribou Skin Clothing of the Igloolik Inuit, Iqaluit, Inhabit Media, 198 pages.

The opening pages of Caribou Skin Clothing of the Igloolik Inuit recount Sylvie Pharand's close collaboration with three generations of clothing specialists in the Igloolik community, and provide an interesting insight into the circuitous history of this publication. In the early 1970s, Pharand began her research as a graduate student at Université Laval working with the French-trained anthropologist Bernard Saladin d'Anglure. Gathering together a notable team of seamstresses, elders, artists, interpreters, and translators-including Seporah Piunngittuq, Jeanine Arnainnuk, Martha Agugaattiaq, Rose Iqallijuq, Annie Majurtuq, Elizabeth Alariaq, Celina Sarpinak Iyerak, and Leah Idlout-Pharand set out to document caribou fur clothing design in the Igloolik region. For almost 40 years the results of her comprehensive and exceptional research remained in manuscript form in the archives of the National Museum of Man (now the Canadian Museum of History). Since the museum's copy was available to serious researchers, the report was nevertheless pivotal in the development of scholarship and publications on Inuit clothing design throughout the 1970s, 1980s, and 1990s. Recently, Sylvie Pharand has returned to this research, working with renewed energy with a second team of specialists in Igloolik, including Leah Aksaajuk Otak, Madeline Piujuq Ivalu, and Susan Angutauttuq Avingaq, to expand and update the original research. The newly released publication provides a wealth of information on caribou fur clothing design (and clothing history) in Igloolik and neighbouring regions, while providing an excellent research model for future work on Inuit material culture and community history.

A summary review such as this can point out only a few of the many strengths of this publication. In addition to discussing the functional attributes of caribou skin clothing and means of clothing production, the author provides keen insights into the social and cultural aspects of Inuit clothing design with a sharp focus on ecology, social philosophy, and the cultural tenets of Inuit society. The author's precise recording of clothing terminology, for example, demonstrates how cultural knowledge is so richly embedded in the Inuktitut language and in the design of clothing forms, particularly as they change over the course of one's life from childhood to maturity. The author's research methodology emphasises the intrinsic value of community collaboration in bringing together individuals whose knowledge, experience, talent, and skill make an exceptional contribution to the project at hand.

Well illustrated with historical and contemporary photographs, the publication describes the variety of clothing types worn by men, women, and children throughout 